\title{
Current developments in toxicology
}

\author{
Hermann M. Bolt
}

Published online: 27 November 2014

(C) Springer-Verlag Berlin Heidelberg 2014

Every year, the editors give an overview over the most intensively studied fields of research and the most cited articles in toxicology. Currently, apoptosis (Kamal et al. 2014; McGrath and Seng 2013; Cardinale et al. 2012, De Brucker et al. 2011), nanotoxicology (Winkler et al. 2013; Johnston et al. 2013; Bohnsack et al. 2012; Greish et al. 2012) and in vitro systems (Li 2014; Bale et al. 2014; Eichbaum et al. 2014; Tiong et al. 2014; Roggen 2014) represent particularly intensively studied topics; they have already been discussed separately (Hengstler et al. 2014; Hammad and Bolt 2014; Bolt 2014). Further cutting-edge topics are metabolism, developmental toxicity, nephrotoxicity, arsenicals, polymorphisms and mycotoxins. To give our readers an overview over the most cited articles in these fields, we summarized the key messages of articles recently published in the Archives of Toxicology (Table 1).

Table 1 Key messages of recent studies in the field of metabolism, developmental toxicity, nephrotoxicity, arsenicals and mycotoxins

\begin{tabular}{|c|c|}
\hline Key message & References \\
\hline $\begin{array}{l}\text { Monoesters are the major metabolites of Di- } n \text {-butyl phthalate and diisobutyl phthalate in humans after oral } \\
\text { application }\end{array}$ & Koch et al. (2012) \\
\hline Arsenic deregulates expression of heme oxygenase 1 , interleukin- 6 and VEGF in endothelial cells & Wang et al. (2012) \\
\hline $\begin{array}{l}\text { A polymorphism of the insulin-like growth factor-binding protein-3 was not associated with urinary bladder } \\
\text { cancer risk }\end{array}$ & Selinski et al. (2012) \\
\hline Arsenite leads to blockage of P53 by HIF-2 alpha & Xu et al. (2012) \\
\hline Maternal glyphosate exposure impairs male offspring in rats & Romano et al. (2012) \\
\hline Salubrinal protects from cadmium-induced toxicity in renal cells & Komoike et al. (2012) \\
\hline $\begin{array}{l}\text { The human hepatoma cell line Huh-7 may represent an alternative to primary human hepatocytes in the study of } \\
\text { drug metabolism }\end{array}$ & Lin et al. (2012) \\
\hline Potassium bromate alters expression of tight junction proteins in renal proximal tubule cells & Limonciel et al. (2012) \\
\hline Arsenic trioxide activates c-Src via NADPH oxidase-produced superoxide & Tseng et al. (2012) \\
\hline $\begin{array}{l}\text { Maternal consumption of the arsenic metabolite methylarsonous acid caused similar proliferative lesions in the } \\
\text { male offspring as inorganic arsenic }\end{array}$ & Tokar et al. (2012) \\
\hline The mytotoxin Ochratoxin A seems to act by epigenetic mechanisms & Jennings et al. (2012) \\
\hline
\end{tabular}

H. M. Bolt $(\bowtie)$

Leibniz Research Centre for Working Environment and Human

Factors at the Technical University of Dortmund (IfADo),

44139 Dortmund, Germany

e-mail: bolt@ifado.de 
Table 1 continued

\begin{tabular}{|c|c|}
\hline Key message & References \\
\hline Diphenyl ditelluride induces hypophosphorylation of intermediate filaments in the cerebral cortex of rats & Heimfarth et al. (2012) \\
\hline Melatonin prevents nephrotoxicity of gentamicin & Lee et al. (2012) \\
\hline Hypothyroidism causes fluctuations in GABAergic interneurons & Shiraki et al. (2012) \\
\hline $\begin{array}{l}\text { Genetic variants of glutathione S-transferase omega 1-1 are associated with the expression of inflammatory } \\
\text { cytokines. }\end{array}$ & Escobar-Garcia et al. (2012) \\
\hline Acrylamide compromises progenitor cells in the hippocampal dentate gyrus of rats & Ogawa et al. (2012) \\
\hline DMSO induces phenotypic alterations and massive alterations in gene expression in stem cells & Pal et al. (2012) \\
\hline The phytochemical glucoraphasatin induces hepatic phase II metabolizing enzymes & Razis et al. (2012) \\
\hline The herbicide glyphosate causes DNA strand breaks and micronuclei in vitro & Koller et al. (2012) \\
\hline Cadmium modulates Ah receptor expression in the rat uterus via the estrogen receptor & Kluxen et al. (2012) \\
\hline A predictive in silico tool for prediction of human bioaccumulation was established & Tonnelier et al. (2012) \\
\hline The microsomal epoxide hydrolase variant 113 His/His reduces detoxification of carcinogenic epoxides & Tumer et al. (2012) \\
\hline UDP GT $1 \mathrm{~A} 1$ is the principle enzyme for puerarin conjugation in human liver & Luo et al. (2012) \\
\hline Estragole, an organic compound used as a food additive, may be a genotoxic hepato-carcinogen & Suzuki et al. (2012) \\
\hline The copper-based drug Casiopeina II-gly simultaneously inhibits oxidative phosphorylation and glycolysis & Marin-Hernandez et al. (2012) \\
\hline The mycotoxins alternariol and alternariol methyl ether induce CYP1A1 in an Ah receptor-dependent manner & Schreck et al. (2012) \\
\hline Perfluorooctane sulfonate acts as a non-genotoxic carcinogen & Jacquet et al. (2012) \\
\hline $\begin{array}{l}\text { A low scaling factor for human inter-individual differences in formaldehyde-induced genotoxicity is recom- } \\
\text { mended }\end{array}$ & Zeller et al. (2012) \\
\hline $\begin{array}{l}\text { Variants of superoxide dismutase and 8-oxoguanine DNA glycosylase conferred increased risk of hypertension } \\
\text { when associated with arsenic exposure }\end{array}$ & Chen et al. (2012) \\
\hline
\end{tabular}

\section{References}

Bale SS, Vernetti L, Senutovitch N, Jindal R, Hegde M, Gough A, McCarty WJ, Bakan A, Bhushan A, Shun TY, Golberg I, DeBiasio R, Usta OB, Taylor DL, Yarmush ML (2014) In vitro platforms for evaluating liver toxicity. Exp Biol Med (Maywood) 239(9):1180-1191. doi:10.1177/1535370214531872

Bohnsack JP, Assemi S, Miller JD, Furgeson DY (2012) The primacy of physicochemical characterization of nanomaterials for reliable toxicity assessment: a review of the zebrafish nanotoxicology model. Methods Mol Biol 926:261-316. doi:10.1007/978-1-62703-002-1_19

Bolt HM (2014) Grouping of nanomaterials for risk assessment. Arch Toxicol. doi:10.1007/s00204-014-1416-2 (this issue)

Cardinale A, Nastrucci C, Cesario A, Russo P (2012) Nicotine: specific role in angiogenesis, proliferation and apoptosis. Crit Rev Toxicol 42(1):68-89. doi:10.3109/10408444.2011.623150

Chen SC, Chen CC, Kuo CY, Chen YY, Lee HS, Wong RH (2012) Elevated risk of hypertension induced by arsenic exposure in Taiwanese rural residents: possible effects of manganese superoxide dismutase (MnSOD) and 8-oxoguanine DNA glycosylase (OGG1) genes. Arch Toxicol 86(6) Special Issue:869-878. doi:10.1007/s00204-011-0797-8

De Brucker K, Cammue BP, Thevissen K (2011) Apoptosis-inducing antifungal peptides and proteins. Biochem Soc Trans 39(5):15271532. doi:10.1042/BST0391527

Eichbaum K, Brinkmann M, Buchinger S, Reifferscheid G, Hecker M, Giesy JP, Engwall M, van Bavel B, Hollert H (2014) In vitro bioassays for detecting dioxin-like activity-application potentials and limits of detection, a review. Sci Total Environ 487:37-48. doi:10.1016/j.scitotenv.2014.03.057

Escobar-Garcia DM, Del Razo LM, Sanchez-Pena LC, Mandeville PB, Lopez-Campos C, Escudero-Lourdes C (2012) Association of glutathione S-transferase Omega 1-1 polymorphisms (A140D and E208K) with the expression of interleukin-8 (IL-8), transforming growth factor beta (TGF-beta), and apoptotic proteaseactivating factor 1 (Apaf-1) in humans chronically exposed to arsenic in drinking water. Arch Toxicol 86(6) Special Issue: 857868. doi:10.1007/s00204-012-0802-x

Greish K, Thiagarajan G, Ghandehari H (2012) In vivo methods of nanotoxicology. Methods Mol Biol 926:235-253. doi:10.1007/ 978-1-62703-002-1_17

Hammad S, Bolt HM (2014) Current developments in nanosafety research. Arch Toxicol. doi:10.1007/s00204-014-1403-7 (this issue)

Heimfarth L, Loureiro SO, Reis KP, Wild L, da Rocha JBT, PessoaPureur R (2012) Diphenyl ditelluride induces hypophosphorylation of intermediate filaments through modulation of DARPP32-dependent pathways in cerebral cortex of young rats. Arch Toxicol 86(2):217-230. doi:10.1007/s00204-011-0746-6

Hengstler JG, Marchan M, Bolt HM (2014) Standard compounds for establishment of in vitro test systems. Arch Toxicol. doi:10.1007/ s00204-014-1398-0

Jacquet N, Maire MA, Landkocz Y, Vasseur P (2012) Carcinogenic potency of perfluorooctane sulfonate (PFOS) on Syrian hamster embryo (SHE) cells. Arch Toxicol 86(2):305-314. doi:10.1007/ s00204-011-0752-8

Jennings P, Weiland C, Limonciel A, Lock EA, Ryan MP, EllingerZiegelbauer H (2012) Transcriptomic alterations induced by Ochratoxin A in rat and human renal proximal tubular in vitro models and comparison to a rat in vivo model. Arch Toxicol 86(4):571-589. doi:10.1007/s00204-011-0780-4

Johnston H, Pojana G, Zuin S, Jacobsen NR, Møller P, Loft S, Semmler-Behnke M, McGuiness C, Balharry D, Marcomini A, Wallin H, Kreyling W, Donaldson K, Tran L, Stone V (2013) Engineered nanomaterial risk. Lessons learnt from completed 
nanotoxicology studies: potential solutions to current and future challenges. Crit Rev Toxicol 43(1):1-20. doi:10.3109/10408444. 2012.738187

Kamal A, Faazil S, Malik MS (2014) Apoptosis-inducing agents: a patent review (2010-2013). Expert Opin Ther Pat 24(3):339-354. doi: $10.1517 / 13543776.2014 .877445$

Kluxen FM, Hofer N, Kretzschmar G, Degen GH, Diel P (2012) Cadmium modulates expression of aryl hydrocarbon receptor-associated genes in rat uterus by interaction with the estrogen receptor. Arch Toxicol 86(4):591-601. doi:10.1007/s00204-011-0787-x

Koch HM, Christensen KLY, Harth V, Lorber M, Bruning T (2012) Di- $n$-butyl phthalate (DnBP) and diisobutyl phthalate (DiBP) metabolism in a human volunteer after single oral doses. Arch Toxicol 86(12):1829-1839. doi:10.1007/s00204-012-0908-1

Koller VJ, Furhacker M, Nersesyan A, Misik M, Eisenbauer M, Knasmueller S (2012) Cytotoxic and DNA-damaging properties of glyphosate and Roundup in human-derived buccal epithelial cells. Arch Toxicol 86(5):805-813. doi:10.1007/s00204-012-0804-8

Komoike Y, Inamura H, Matsuoka M (2012) Effects of salubrinal on cadmium-induced apoptosis in HK-2 human renal proximal tubular cells. Arch Toxicol 86(1):37-44. doi:10.1007/ s00204-011-0742-x

Lee IC, Kim SH, Lee SM, Park SC, Kim HC, Kim JC (2012) Melatonin attenuates gentamicin-induced nephrotoxicity and oxidative stress in rats. Arch Toxicol 86(10):1527-1536. doi:10.1007/ s00204-012-0849-8

Li AP (2014) In vitro human hepatocyte-based experimental systems for the evaluation of human drug metabolism, drug-drug interactions, and drug toxicity in drug development. Curr Top Med Chem 14(11):1325-1338. doi:10.2174/1568026614666140506114411

Limonciel A, Wilmes A, Aschauer L, Ryan MP, Lock EA, Jennings P (2012) Oxidative stress induced by potassium bromate exposure results in altered tight junction protein expression in renal proximal tubule cells. Arch Toxicol 86(11):1741-1751. doi:10.1007/ s00204-012-0897-0

Lin J, Schyschka L, Muhl-Benninghaus R, Stockle U, Nussler AK, Ehnert S (2012) Comparative analysis of phase I and II enzyme activities in 5 hepatic cell lines identifies Huh-7 and HCC-T cells with the highest potential to study drug metabolism. Arch Toxicol 86(1):87-95. doi:10.1007/s00204-011-0733-y

Luo CF, Cai B, Hou N, Xiong W, Luo JD, Chen MS (2012) UDPglucuronosyltransferase $1 \mathrm{~A} 1$ is the principal enzyme responsible for puerarin metabolism in human liver microsomes. Arch Toxicol 86(11):1681-1690. doi:10.1007/s00204-012-0874-7

Marin-Hernandez A, Gallardo-Perez JC, Lopez-Ramirez SY, MaciasSilva M, Moreno-Sanchez R, Rodriguez-Enriquez S (2012) Casiopeina II-gly and bromo-pyruvate inhibition of tumor hexokinase, glycolysis, and oxidative phosphorylation. Arch Toxicol 86(5):753-766. doi:10.1007/s00204-012-0809-3

McGrath P, Seng WL (2013) Use of zebrafish apoptosis assays for preclinical drug discovery. Expert Opin Drug Discov 8(10):11911202. doi:10.1517/17460441.2013.825244

Ogawa B, Wang LY, Ohishi T, Taniai E, Akane H, Suzuki K, Mitsumori K, Shibutani M (2012) Reversible aberration of neurogenesis targeting late-stage progenitor cells in the hippocampal dentate gyrus of rat offspring after maternal exposure to acrylamide. Arch Toxicol 86(5):779-790. doi:10.1007/s00204-012-0801-y

Pal R, Mamidi MK, Das AK, Bhonde R (2012) Diverse effects of dimethyl sulfoxide (DMSO) on the differentiation potential of human embryonic stem cells. Arch Toxicol 86(4):651-661. doi:10.1007/s00204-011-0782-2

Razis AFA, De Nicola GR, Pagnotta E, Iori R, Ioannides C (2012) 4-Methylsulfanyl-3-butenyl isothiocyanate derived from glucoraphasatin is a potent inducer of rat hepatic phase II enzymes and a potential chemopreventive agent. Arch Toxicol 86(2):183194. doi:10.1007/s00204-011-0750-x
Roggen EL (2014) In vitro approaches for detection of chemical sensitization. Basic Clin Pharmacol Toxicol 115(1):32-40. doi:10.11 11/bcpt.12202

Romano MA, Romano RM, Santos LD, Bernardi MM, Nunes MT, de Oliveira CA (2012) Glyphosate impairs male offspring reproductive development by disrupting gonadotropin expression. Arch Toxicol 86(4):663-673. doi:10.1007/s00204-011-0788-9

Schreck I, Deigendesch U, Burkhardt B, Marko D, Weiss C (2012) The Alternaria mycotoxins alternariol and alternariol methyl ether induce cytochrome P450 1A1 and apoptosis in murine hepatoma cells dependent on the aryl hydrocarbon receptor. Arch Toxicol 86(4):625-632. doi:10.1007/s00204-011-0781-3

Selinski S, Lehmann ML, Blaszkewicz M, Ickstadt K, Hengstler JG, Golka K (2012) Urinary bladder cancer risk in relation to a single nucleotide polymorphism (rs2854744) in the insulin-like growth factor-binding protein-3 (IGFBP3) gene. Arch Toxicol 86(2):195-203. doi:10.1007/s00204-011-0747-5

Shiraki A, Akane H, Ohishi T, Suzuki K, Mitsumori K, Shibutani M (2012) Similar distribution changes of GABAergic interneuron subpopulations in contrast to the different impact on neurogenesis between developmental and adult-stage hypothyroidism in the hippocampal dentate gyrus in rats. Arch Toxicol 86(10):1559 1569. doi:10.1007/s00204-012-0846-y

Suzuki Y, Umemura T, Hibi D, Yanai T, Nishikawa A, Ogawa K (2012) Possible involvement of genotoxic mechanisms in estragole-induced hepatocarcinogenesis in rats. Arch Toxicol 86(10):1593-1601. doi:10.1007/s00204-012-0865-8

Tiong HY, Huang P, Xiong S, Li Y, Vathsala A, Zink D (2014) Druginduced nephrotoxicity: clinical impact and preclinical in vitro models. Mol Pharm 11(7):1933-1948. doi:10.1021/mp400720w

Tokar EJ, Diwan BA, Thomas DJ, Waalkes MP (2012) Tumors and proliferative lesions in adult offspring after maternal exposure to methylarsonous acid during gestation in CD1 mice. Arch Toxicol 86(6) Special Issue:975-982. doi:10.1007/s00204-012-0820-8

Tonnelier A, Coecke S, Zaldivar JM (2012) Screening of chemicals for human bioaccumulative potential with a physiologically based toxicokinetic model. Arch Toxicol 86(3):393-403. doi:10.1007/ s00204-011-0768-0

Tseng HY, Liu ZM, Huang HS (2012) NADPH oxidase-produced superoxide mediates EGFR transactivation by c-Src in arsenic trioxide-stimulated human keratinocytes. Arch Toxicol 86(6) Special Issue:935-945. doi: 10.1007/s00204-012-0856-9

Tumer TB, Sahin G, Arinc E (2012) Association between polymorphisms of EPHX1 and XRCC1 genes and the risk of childhood acute lymphoblastic leukemia. Arch Toxicol 86(3):431-439. doi:10.1007/s00204-011-0760-8

Wang L, Kou MC, Weng CY, Hu LW, Wang YJ, Wu MJ (2012) Arsenic modulates heme oxygenase-1, interleukin-6, and vascular endothelial growth factor expression in endothelial cells: roles of ROS, NF-kappa B, and MAPK pathways. Arch Toxicol 86(6):879-896. doi:10.1007/s00204-012-0845-z

Winkler DA, Mombelli E, Pietroiusti A, Tran L, Worth A, Fadeel B, McCall MJ (2013) Applying quantitative structureactivity relationship approaches to nanotoxicology: current status and future potential. Toxicology 313(1):15-23. doi:10.1016/j.tox.2012.11.005

Xu Y, Li Y, Pang Y, Ling M, Zhou JW, Wang XR, Liu QZ (2012) Blockade of p53 by HIF-2 alpha, but not HIF-1 alpha, is involved in arsenite-induced malignant transformation of human bronchial epithelial cells. Arch Toxicol 86(6):947-959. doi:10.1007/ s00204-012-0810-x

Zeller J, Hogel J, Linsenmeyer R, Teller C, Speit G (2012) Investigations of potential susceptibility toward formaldehyde-induced genotoxicity. Arch Toxicol 86(9):1465-1473. doi:10.1007/ s00204-012-0830-6 